\title{
Evaluation of Social Media Impact on UN Agencies in Yemen
}

\author{
Sabrin Al-Aghbari ${ }^{1}$, Wail Alhakimi ${ }^{2}$ \\ ${ }^{1}$ School of Business, Lebanese International University, Yemen \\ ${ }^{2}$ Associate Professor of Marketing, Taiz University, Yemen \\ Correspondence: Wail Alhakimi, Taiz University, Yemen. E-mail: wail.alhakimi@taiz.edu.ye
}

Received: April 11, 2021

Accepted: August 27, 2021 Online Published: September 10, 2021

doi:10.48110/joi.v2i2.35

URL: https://doi.org/10.48110/joi.v2i2.35

\begin{abstract}
Nowadays, the whole world is becoming a small village. Globalization is the fact of living everywhere. The use of the internet and advanced technology integrates with all different life angles and can never be neglected in our daily lives. As part of this technology advancement, social media has broken into our daily lives and you can find these platforms or at least one of them in every home. Social media is now part of any business everywhere, and all businesses now think of it as the first marketing option for all kind of services provided. Starting from the fact that social media is a critical tool for any business, this study analyzes how social media can affect the work of non-profit organizations. The study targets UN agencies in Yemen. To assess and evaluate this impact of social media on UN agencies in Yemen, a questionnaire of 25 questions was constructed and circulated among different people in these agencies. As in the case of other previous studies, the results of this study show that there is a great positive impact of social media on brand awareness, community engagement and organizations performance. Similar to other studies, fundraising is used as purpose of social media use, but it still needs more strategic plans in the future to be applied efficiently. UN agencies have to keep on more strategic plans to keep their social media platforms into their own targets.
\end{abstract}

Keywords: Social Media, Brand Awareness, Community Engagement, Organizations Performance, Fundraising, UN Agencies, Yemen

\section{Introduction}

As a non-developed country (one of the third world countries), Yemen wasn't expected to flourish in terms of advanced technology. Still, social media in Yemen is now the basic mean for almost all business, which became a mean for marketing like all countries around the world. Because of social media's wide acceptance and its sufficient impact on any kind of business globally, it became the first approach when it comes to marketing or branding, as businesses always seek the best use of its advantage (Durkin, McGowan, \& McKeown, 2013). Now, almost all non-profit organizations globally follow the same approach including the organizations in Yemen.

In the past, marketing used the traditional means like magazines, newspaper, radio, and paper distribution (brochures and leaflet) However, all businesses now are converting to the use of social media to reach their targeted customers or entities with their ideas, products and general thoughts (Logan, Bright, \& Gangadharbatla, 2012). The huge behavior changes of consumers pushed organizations mangers to have a new method of following online platforms (Tiago \& Verissimo, 2014).

If you compare these organizations in the past, you would not find a division called "Communication" like what we have now. Moreover, the effectiveness proved by social media is considered cheap comparing to the old means. The impact of social media in terms of the word of mouth generated by social media and the cost of effectiveness of social media platforms (Facebook and Twitter) make it an alternative to the old-style advertising (Zhang, Johnston, \& Shao, 2014).

Although it's believed in Yemen, like in all other places in the world, that social media has a massive impact either in terms of cost or final results, it's still difficult to fully depend only on social media. There are still many rural areas, where people have almost no access to internet or have not heard of social media in their entire lives. For that, all non-profit organizations still use other old school means for some of their marketing and branding, while keeping social media as their king force mean. This study aims at examining how social media serves UN agencies in order to serve the communities, assessing how social media can influence the organization's performance, and examining the role of social media in fundraising. 


\section{Literature Review}

\subsection{Social Media}

Social media is considered one of the newest means for communication using technology through Internet (Kane, Alavi, \& Borgatti, 2014). Millions around the world use social media but researchers stated that the business applications within social media are not yet settled either to be considered social media platforms or not (Kane et al., 2014). However, some studies claimed that non-profit organizations use social media less comparing to other organizations. These studies by Waters and Jamal (2011) and Wilcox-Ugurlu (2011) shed light on the three purposes of social media use. First, social media builds a communication bridge between organizations and the community, which allows mutual conversations (Guo \& Saxton, 2014; Lovejoy \& Saxton, 2012). Second, advocacy is another purpose for what social media is used for (Bortree \& Seltzer, 2009; Briones, Kuch, Liu, \& Jin, 2011). Third, its purpose is to enlarge the circle of individual donors, which helps in financial mobilization (Greenberg \& MacAulay, 2009; Waters, Burnett, Lamm, \& Lucas, 2009). Non-profit organizations use different platforms to have better communication with their stakeholders and have more followers. Big non-profit organizations use Facebook and Twitter to keep consistent communication with stakeholders more than they do using traditional websites (Lovejoy \& Saxton, 2012).

According to Mical (2018), the effective use of social media platforms has many positive impacts on non-profit organization. The fact that the targeted audience are looking forward to shifting into a brief channel that can easily offer digested updates instead of long detailed pace of content played a major role of the effectiveness use of social media. These platforms help audience and donors reach such a need easily. Considering those non-profit organizations that conduct activities with time constraints, such platforms enable them to reach their audience with much easy and timely engagement.

Moreover, Dighe (2002), Gupta et al. (2013) and Govette (2014) argued that there are many benefits of social media platforms for non-profit organizations, which could be categorized into two main benefits: nonfinancial and financial benefits. Getting global attention by huge audience and sharing information can frame the core of the nonfinancial benefits (Kanter \& Paine, 2012). Moreover, another nonfinancial benefit of social media platforms is that they offer a tool for consistent feedback (Kanter \& Paine, 2012; Foster, 2014; Khan, Hoffman, \& Misztur, 2014).

\subsection{Branding Awareness in Social Media Context}

The use of social media that allows people to share, react, and create content within platforms allows organizations even those with a low budget to reach more audience and talk about the organizations. Social media is the tool that creates a name and a brand for the origination which leads to the impact of donor. The American Marketing Association (2014) defined brand as a name, a term, a design, a sign, or a symbol or just a mix of all these words to distinguish a good service provided to their audience among all other competitors. From marketing perspective, awareness means how famous a brand is and how well-known a product or service is. Therefore, brand awareness indicates that a brand is distinguished by a specific customer and related to a specific product or service. Top-ofMind awareness is considered the highest level of brand awareness (Aaker, 1991). This level of awareness is accomplished whenever the brand is remembered as first name when measured by the unaided recall test (Jeffery, 2010). According to Van Haaften (2017), top-of-mind awareness is already dominating the person's mind when thinking of the product or service.

\subsection{Community Engagement}

The social media platforms started a new way for organizations to build community engagement and create a relationship with their stakeholders (Briones et al., 2011). Social media does not only create current community engagement, but it also builds potential engagement with the stakeholders, audience, and even donors through open sharing information channels in real time (Kaplan \& Haenlein, 2010). Through social media, you can find the most cost-effective platforms to communicate, start a dialogue and mobilize activators in best time manner (Kaplan \& Haenlein, 2010).

There are different definitions of community engagement, which reflect it in many ways but still have things in common. According to Hollebeek (2011), customer engagement means that the consumer interacts, builds dialogues and saves a value with the organization through making personal experiences. However, Vivek, Beatty and Morgan (2012) defined community engagement as the level of intensity of one's connectivity and participation with the organization's activities, which are initiated by either the consumer or the organization. 
Organizations use social media platforms as a marketing tool to promote their services or even products and build visibility through these platforms on the internet (Salem \& Salem, 2019). It is true that almost all companies and organizations fully understand the importance of these online platforms to reach their audience and customers (Salem \& Salem, 2019). However, they are also aware of the difficulties they face to keep their recognition, loyalty, and brand awareness (engagement) (Ismail, 2017). The organizations' point of view of social media is to use it to conduct effective advertisement campaign and covert the users to be a part of these campaigns. In addition, they involve those users into the development of their services by creating a platform for them, which they can share their own ideas and build engagement (Becker et al., 2013).

Now, social media marketing (SMM) is considered the most effective marketing tool that builds strong relationship with customers. Therefore, strengthening the purchasing and engaging with brands are the most important goals to be achieved for marketing communication (Kim \& Ko, 2012). Though it is often intertwined with customer experience (CX) and customer relationship management (CRM), customer engagement (CE) is defined by Paul Greenberg as "the continuous interaction among customers and company, offered by the company and chosen by the customer" (Sashi, 2012). According to Kumar (2013), companies in general are changing from product-sales philosophy into customer engagement philosophy.

\subsection{Organization performance}

Organization performance is defined as the way the organization creates a balance between the cost of its financial goals and marketing criteria (Li, Ragu-Nathan, Ragu-Nathan, \& Subba Rao, 2006). Another definition of organization performance is the output of many factors like job process, teamwork, relations and communication, leadership, job atmosphere that creates innovation, policy, loyalty, creativity, culture, and image. According to Chen and Paulraj (2004), organization performance converts input to output to accomplish specific outcomes. According to his definition, performance tells about the relationship between minimal and effective cost (economy), between considerable output (efficiency) and effective cost, and between output and accomplished outcome (effectiveness). Moreover, organization performance has a different definition, which says that there are three angles shaping performance (outcome), namely financial performance (income, returns on assets, and return on investment), product market performance (sales and market share), and shareholder return (total shareholder return and economic value added).

Because changes are something consistent, organizations must adapt to changes and act accordingly to get individuals deal with faced challenges regularly. Customers always expect quick responses to their frequent changing needs and requirements. Rapid adaption surfaces the adjustments and the modifications, which are made by the organization and its component to respond to these changes according to the requirement of customers and the internal and external environment change (Cameron, 1984). These days, organizations must develop their learning skills to become more flexible to respond to consumers' requirements, and that is why they are keen to have employees with effective skills to do so (Dubois \& Rothwell, 2004). According to Byham and Moyer (1996), organizations are supposed to hire employees who are capable to deal with such internal and external challenges in the surrounded environment, which will allow the organizations to predict these changes and act with prompt response in regular matters accordingly.

It has been a rule that originations work on spending less time when marketing new idea, product or a service from competitive advantage perspective. The time of market is the time consumed from the moment the product or service is initiated as an idea until it is initiated in the market (Lines, 2015). Moreover, time of market for a new project or service is defined as the competitive advantage source (Afonso, Nunes, Paisana, \& Braga, 2008).

Cost reduction is the achievement of real reduction of the unit cost of the product or the service that has been reduced without any effect of the proper use of this product or service intentionally. It is very important not to mix the concept of reducing the cost with saving or controlling the cost, as saving cost could be a temporary action that can affect the quality of the product or the service provided. Still, reducing cost should be a real reduction of cost while keeping the very high standard of the product or the service (Barbole, Nalwade, \& Parakh, 2013).

Innovation was defined as a collective phenomenal effort by a group of people interacting with others and not by individuals. Such efforts are gathered to effectively integrate a new idea development and a new market development (Myers \& Marquis, 2005). Moreover, innovation has a firm connection with organizational learning, which is the organization ability to create, admit, get a new idea into action, and process the project or the service (Calantonea, Cavusgil, \& Zhao, 2002). In addition, innovation is also known as a way of developing a fresh idea or an innovation and introducing it into the market as project or service (Thornhill, 2006). Innovation depends on many factors, which are technological, organizational, financial, and commercial actions (Vacek, 2009). Organizations must have the prompt abilities to respond to these internal and external environmental challenges. 
The importance of social media use is that innovation is encouraged through the consistent observation of customers' feedback, perspectives and interactions (Matuszak, 2007; Tapscott \& Williams, 2006). It was stated that innovation plays a major role in the development of the projects in the industry through the introduction of a new product or service (Chaston \& Mangles, 1997).

\subsection{Fundraising}

Getting the attention of charitable donations through individuals or cooperation for social program is a critical step in the strategic plan for any organization for many reasons. Organizations do not have these platforms to reflect the real suffering of the communities they serve. They will never gain support and trust which may threat their existence. Now, social media platforms like Facebook and Twitter are used to connect with donors using all the features in these platforms ("How nonprofits can use social media", 2020). Beside the revenue increment, it plays a major role in raising the awareness of the community of the organization purpose and mission. Soliciting donations through individuals and cooperation enables a financial network, which could be accessed by nonprofits annually and can result in the expansion of the programs of organization's mission. On the other hand, the world has noticed a huge increase in the number of organizations, and the competition is getting intense for the donor dollar. It is important to mention that the market of donation is not stable due to many facts such as the unstable world economy, politics, and tax. Therefore, the charity society including nonprofit organizations must think creatively of different methods for donor consistency (Froelich, 1999).

Organizations are searching for an alternative tool that combines finance efficiency and fundraising effectiveness. Technology will play the first and the most important role for donor collection, as all people are now connected virtually (Wasley, 2009). Using social media tools for fund increment enables organizations to capitalize on social media network effect and impulse donors (Saxton, 2013). Now, there are very quick applications used through media, which allow individual donors to donate directly to the organization (Saxton, 2013).

According to different studies, around $21 \%$ increment of fundraising occurred through just a click on social media. Social media users are motivated to donate especially when they are motivated about the activity of organizations on social media platforms. Donors see that social media platforms are quick, safe and effective channels to donate (McCall, 2019). According to a study conducted in 2010, around 200 charities use a minimum of one platform of social media to come up with donations, and all these charities leaders confessed in interviews about the importance of social media in this regard (Barnes, 2011). According to a study, most prominent of 200 nonprofit organizations are seeking a minimum of one of their social media platforms to make and execute donations (Barnes \& Mattson, 2008).

Although fundraising through social media is still new, raising fund through the use of the internet is not new. It was stated that many of the big charities started gathering fund through the internet in the late 1990s. Still, the advocacy of using the social media and the internet is still in progress as a critical sector for giving (Waters, 2007). One example of this is The Chronicle of Philanthropy, 2011, which started with a list of 9 charities in 2011 and indicated that the use of social media increased by 10 percent after the online fundraising. ARC (The American Red Cross) managed to increase around $19 \%$ of its fund, which is around 188 million US dollar through online donation (Indiana University, 2011).

Since the beginning of nonprofit organizations in the United States, the funds process has started to be a debated subject. Through the last decade, fundraising has witnessed a massive change. For that, all non-profit organizations should get ready to adapt these changes in order to survive in the increasing competitive market. Beside the change in the economy, we are in a fresh era of change in technology and communication, which affect the way organizations' network deals with donors, volunteers, members of board and other organizations. Nowadays, the whole society fully depends on social media and networking, and social media has dramatically influenced the way non-organizations raise awareness of their causes. Contacting donors via discussions or email solicitation don't happen anymore because the majority of such fundraising approaches happen through social media platforms like Facebook, Twitter, etc. For instance, a new research found that around 75 percent of 980 organizations are using the Facebook platform, which has over 220 million of users around the world (Wasley, 2009). In addition, Facebook cause, which is the most well-known social networking application used by nonprofit organizations, has over 24 million of active users on monthly basis, who are allowed to get their friends into the cause, keep all people connected into the cause, and most importantly advocate money into the cause.

Many researchers have discussed the use of social media for all kinds of businesses, and identified famous platforms like Facebook, Twitter, and You-Tube (Berman, Abraham, Battino, Shipnuck, \& Neus, 2007). Social media creates many chances for business mainly in mass communication with their targeted audience (Vorvoreanu, Boisvenue, Portela, \& Bao, 2013). 


\section{Methods}

This study follows the descriptive quantitative approach, as it is the most suitable design for the study. According to the UN Yemen Report (2020), there are 21 resident and non-resident agencies in Yemen (See Table 1).

Table 1. UN Entities in Yemen

\begin{tabular}{|c|c|}
\hline UN Agency Name & Website \\
\hline $\begin{array}{l}\text { FAO (Food \& Agriculture Organization of the } \\
\text { United Nation }\end{array}$ & http://www.fao.org/home/en/ \\
\hline ILO (International Labour Organization & https://www.ilo.org/global/lang--en/index.htm \\
\hline IMF (International Monetary Fund) & https://www.imf.org/external/index.htm \\
\hline IOM (UN Migration) & https://www.iom.int/ \\
\hline OCHA & https://www.unocha.org/yemen \\
\hline OHCHR & https://www.ohchr.org/EN/pages/home.aspx \\
\hline UN HABITAT & https://unhabitat.org/ \\
\hline UN WOMEN & https://www.unwomen.org/en \\
\hline UNDP & https://www.ye.undp.org/content/yemen/en/home/ \\
\hline UNESCO & https://en.unesco.org/fieldoffice/doha \\
\hline UNFPA & https://yemen.unfpa.org/ \\
\hline UNHCR & https://www.unhcr.org/ \\
\hline UNIC & http://bit.ly/3nD45cY \\
\hline UNICEF & https://www.unicef.org/yemen/ \\
\hline UN MISSION & $\begin{array}{l}\text { https://dppa.un.org/en/mission/unmha-hudaydah- } \\
\text { agreement }\end{array}$ \\
\hline UNODC & http://bit.ly/2KzKqfv \\
\hline UNOPS & https://www.unops.org/ \\
\hline UN VOLUNTEERS & https://www.unv.org/ \\
\hline WFP & https://www.wfp.org/countries/yemen \\
\hline WHO & http://www.emro.who.int/countries/yemen/index.html \\
\hline WB (The World Bank) & https://www.worldbank.org/en/country/yemen \\
\hline
\end{tabular}

The study targets a represented group of communication people, operation and programs leaders in a number of resident UN agencies in Yemen. As it is difficult to get a fixed total number of the targeted population, there is usually a minimum of 2 communication people in each agency and somehow a big number of operations and programs leaders. The sampling is usually gathered from those who can comfortably provide the information, which is called convenience sampling. It is usually difficult and costly to reach the sampling at the exact time of data collection, so the convenience sampling is selected. Therefore, more sampling gives best accurate results (Sekaran \& Bougie, 2016). The sample that is between 30-500 is considered a suitable sample for a study (Roscoe, 1975). This study targets 110 respondents.

The survey is divided into four parts and five-points Likert scale was used to measure the attitudes and opinions of the respondents. The first part is to assess the level of brand awareness the UN employees believe social media can create. Six questions were adopted from the study done by Mridha (2016). The second part is to evaluate the level of community engagement the UN employees believe they can get through the activities of social media. This part needs to measure how employees in different departments within the organization think of linking their actual work to social media to come up with a great level of community engagement. Five questions were adopted from two studies done by Vanga, Yang and Andersson (2019) and Cuillierier (2016). The third part of the survey assesses the impact of social media on organization performance. Six questions were adopted from the study done by Dodokh (2017). The last part of the questionnaire studies the effect of social media on organization fundraising. Three questions are adopted to assess the availability of strategic plans to raise fundraising and whether social media tools can be part of these tools (Laird, 2010). The overall reliability is achieved (Cronbach alpha $=0.776$ ) and the validity of the instrument was measured using correlation analysis which shows a statistically significant correlation between the overall average of the study constructs and its items, indicating that the construct explains adequate variance in its items and thus has good validity to measure what is it supposed to measure.

\section{Finding}

The total survey collected was 110 . Almost half of the respondents are females $(48.2 \%)$, and $51.8 \%$ of them are males. Moreover, $34.5 \%$ of the respondents stated they have been working for 1-2 years at the UN; $30.9 \%$ for 34 years; $10 \%$ for 5-6 years; and 24.5\% have been working for over 6 years at the UN. Out of 110 respondents, 
$25.5 \%$ responded that they work in communication; $26.4 \%$ of them work in operations; $33.6 \%$ in programs; and $14.5 \%$ in other departments, $6.3 \%$ of them stated they work in cluster; $12.5 \%$ in HR; $6.3 \%$ in IT; $6.3 \%$ in monitoring and evaluation; $18.8 \%$ in procurement; $12.5 \%$ in program support; $6.3 \%$ in project support unit; $6.3 \%$ in projects; $6.3 \%$ in project management; $6.3 \%$ in protection; and $12.5 \%$ in supply and logistics.

Out of 110 respondents, $45.5 \%$ always use social media in their regular day; $3.6 \%$ of them hardly ever use it; $1.8 \%$ of them never use it; $28.2 \%$ often use social media in their regular day; $20.9 \%$ sometimes use social media.

Table 2 shows the descriptive statistics of the brand awareness dimension. As seen in the table, item 4 (You can recognize more logos of different UN agencies through social media platforms.) is ranked the highest in the level of agreement among the respondents of the study (Mean $=3.99 ; \mathrm{SD}=0.70$ ). On the other hand, item 6 (The UN agencies keep you informed on issues relevant to their mission and vision through social media.) is ranked the lowest in the level of agreement (Mean $=3.66 ; \mathrm{SD}=0.84$ ) with $73.2 \%$ rate of agreement. The overall statistics of the brand awareness dimension shows that there is high agreement (Mean $=3.82 ; \mathrm{SD}=0.50$ ) with $76.3 \%$ rate of agreement.

Table 2. Statistics of the Brand Awareness Dimension

\begin{tabular}{llcccc}
\hline No. & \multicolumn{1}{c}{ Item } & Mean & SD & \% & label \\
\hline $\mathbf{1}$ & $\begin{array}{l}\text { You can recognize the organization various activities } \\
\text { through social media }\end{array}$ & 3.94 & 0.69 & $78.8 \%$ & High \\
$\mathbf{2}$ & $\begin{array}{l}\text { You can recall different programs, events, activities } \\
\text { of UN agencies through social media. }\end{array}$ & 3.75 & 0.78 & $75.0 \%$ & High \\
$\mathbf{3} \quad \begin{array}{l}\text { From social media official page of certain UN } \\
\text { agencies, you can recall their brand mission and } \\
\text { vision. }\end{array}$ & 3.80 & 0.81 & $76.0 \%$ & High \\
$\mathbf{4} \quad \begin{array}{l}\text { You can recognize more logos of different UN } \\
\text { agencies through social media platforms. }\end{array}$ & 3.99 & 0.70 & $79.8 \%$ & High \\
$\mathbf{5} \quad \begin{array}{l}\text { Through the agency name, you can recognize various } \\
\text { of its activities. } \\
\text { The UN agencies keep you informed on issues } \\
\text { relevant to their mission and vision through social } \\
\text { media. }\end{array}$ & 3.76 & 0.70 & $75.2 \%$ & High \\
Brand Awareness & $\mathbf{3 . 8 2}$ & $\mathbf{0 . 5 0}$ & $\mathbf{7 6 . 3 \%}$ & High \\
\hline
\end{tabular}

In addition, one sample $\mathrm{T}$ test was conducted. The level of brand awareness is high (Mean $>=3.4 ; \mathrm{t}=8.781 ; \mathrm{p}<0.05$ ), indicating that the targeted audience are highly aware of the role of social media in raising organizations' brands. The results shows that there are no statistically significant differences in the responses of the study sample regarding the impact of brand awareness according to the department they work in $(F=2.500 ; p>0.05)$, indicating that their responses are similar to some extent. However, the mean of the communication department is the highest $(M=4.0238)$, whereas the mean of the programs department is the lowest $(M=3.6982)$.

The results shows that $47.3 \%$ responded that they do not interact with organization brands on social medial, whereas $52.7 \%$ of them responded that they interact with organization brands on social media. $4.4 \%$ of the study sample responded that they extremely often interact with organization/ company brands on social media platforms, $17.3 \%$ of them stated that they never do that, $23.6 \%$ of them stated they do not do that so often, and $24.5 \%$ of them do that very often. Out of 110 respondents, $8.2 \%$ of the respondents stated that they interact with organization brands on social media by commenting on the post; $26.4 \%$ of them stated that they do not interact at all; $46.4 \%$ stated they do that by liking the post and the tweet; and $19.1 \%$ of them stated they do that by sharing the post and the tweet.

As shown in Table 3, the results indicate that there is no significant association between the working years at the $\mathrm{UN}$ in Yemen and the belief of respondents in the engagement of social media $(\mathrm{x} 2=2.843, \mathrm{p}>0.05)$. Thus, there are no significant differences in their responses. However, 5-6 years are the highest (63.6\%), and 1-2 years are the lowest $(42.1 \%)$. 
Table 3. Social Media Engagement and Working Years

\begin{tabular}{|c|c|c|c|c|c|c|}
\hline & & & \multicolumn{2}{|c|}{$\begin{array}{c}\text { Do you interact with organization brands } \\
\text { on social media? }\end{array}$} & \multirow{2}{*}{$\mathrm{X} 2$} & \multirow{2}{*}{$\mathrm{p}$} \\
\hline & & & yes & no & & \\
\hline \multirow{8}{*}{$\begin{array}{l}\text { How long have } \\
\text { you worked with } \\
\text { the UN in Yemen? }\end{array}$} & \multirow{2}{*}{ 1-2 years } & No & 16 & 22 & \multirow{8}{*}{$2.843^{\mathrm{a}}$} & \multirow{8}{*}{.416} \\
\hline & & $\%$ & $42.1 \%$ & $57.9 \%$ & & \\
\hline & \multirow{2}{*}{ 3-4 years } & No & 19 & 15 & & \\
\hline & & $\%$ & $55.9 \%$ & $44.1 \%$ & & \\
\hline & \multirow{2}{*}{ 5-6 years } & No & 7 & 4 & & \\
\hline & & $\%$ & $63.6 \%$ & $36.4 \%$ & & \\
\hline & \multirow{2}{*}{ over 6 years } & No & 16 & 11 & & \\
\hline & & $\%$ & $59.3 \%$ & $40.7 \%$ & & \\
\hline
\end{tabular}

Table 4 shows the descriptive statistics of the organization performance dimension. As seen in the Table, item 2 (Organizations should always keep looking for new innovative ways to deliver their services to the community they serve) is ranked the highest in the level of agreement (Mean=4.57; $\mathrm{SD}=0.53$ ) with $91.4 \%$ rate of agreement. On the other hand, item 1 (Do organizations have the ability to adapt to internal and external changes to keep their competitive advantage through social media) is ranked the lowest in level of agreement (Mean $=3.67 ; \mathrm{SD}=0.76$ ) with $73.4 \%$ rate of agreement. The overall statistics of the organization performance dimension indicates that the level of agreement is high (Mean $=4.11 ; \mathrm{SD}=0.43$ ) with $82.2 \%$ rate of agreement.

Table 4. The statistics of the organization performance dimension

\begin{tabular}{|c|c|c|c|c|c|}
\hline no & item & Mean & SD & $\%$ & label \\
\hline 1 & $\begin{array}{l}\text { Do organizations have the ability to adapt to } \\
\text { internal and external changes to keep their } \\
\text { competitive advantage through social media? }\end{array}$ & 3.67 & 0.76 & $73.4 \%$ & High \\
\hline 2 & $\begin{array}{l}\text { Organizations should continue to invest in } \\
\text { advanced technology to improve their services. }\end{array}$ & 4.35 & 0.70 & $87.0 \%$ & Very High \\
\hline 3 & $\begin{array}{l}\text { The organization uses social media policy for } \\
\text { engagement to maintain communication with cost } \\
\text { reduction. }\end{array}$ & 3.76 & 0.82 & $75.2 \%$ & High \\
\hline 4 & $\begin{array}{l}\text { While using social media, the organization is } \\
\text { seeking to reduce the wasteful use of resources } \\
\text { (raw material like paper, banners, etc.) }\end{array}$ & 4.01 & 0.91 & $80.2 \%$ & High \\
\hline 5 & $\begin{array}{l}\text { The organization through social media can reach } \\
\text { more people globally and internally while working } \\
\text { on economies of scale (more activities reach with } \\
\text { less cost). }\end{array}$ & 4.31 & 0.63 & $86.2 \%$ & Very High \\
\hline \multirow[t]{2}{*}{6} & $\begin{array}{l}\text { Organizations should always keep looking for new } \\
\text { innovative ways to deliver their services to the } \\
\text { community they serve. }\end{array}$ & 4.57 & 0.53 & $91.4 \%$ & High \\
\hline & Organization performance & 4.11 & 0.43 & $82.2 \%$ & High \\
\hline
\end{tabular}

The results reveal that there is a significant difference in the responses of the study sample regarding the impact of organization performance according to their department $(\mathrm{F}=3.987 ; \mathrm{p}<0.05)$, indicating that their responses are not the same. To highlight the differences, post hoc test (LSD) for multiple comparisons was conducted. As seen in Table 5, the staistically signficant differences regarding the impact of the orgnization performance are in favor of those working in communication department over those working in operations, programs, and other depratments $(\mathrm{p}<0.05)$. This indciates that the level of agreement of those working in communication is significantly different from those working in other departments in that they believe organizatipon performance has an impact on organization performance. 
Table 5. Post hoc test for organization performance and working department

\begin{tabular}{ccccc}
\hline \multirow{2}{*}{ (I)department } & (J) department & $\begin{array}{c}\text { Mean Difference } \\
(\mathbf{I}-\mathbf{J})\end{array}$ & Std. Error & Sig. \\
& operations & $.35057^{*}$ & .11017 & .002 \\
\multirow{3}{*}{ communication } & programs & $.23874^{*}$ & .10415 & .024 \\
& others & $.33333^{*}$ & .13031 & .012 \\
& communication & $-.35057^{*}$ & .11017 & .002 \\
operations & programs & -.11184 & .10313 & .281 \\
& others & -.01724 & .12949 & .894 \\
& communication & $-.23874^{*}$ & .10415 & .024 \\
& operations & .11184 & .10313 & .281 \\
programs & others & .09459 & .12441 & .449 \\
& communication & $-.33333^{*}$ & .13031 & .012 \\
& operations & .01724 & .12949 & .894 \\
& programs & -.09459 & .12441 & .449 \\
\hline
\end{tabular}

As for the fundraising, the results reveal that $15.5 \%$ of the respondents responded that their organizations do not have a strategic plan for social media, whereas $84.5 \%$ of them responded that their organizations have a strategic plan for social media. Out of the 110 respondents, $29.1 \%$ of the respondents stated that their originations' strategic plan does not include a fundraising strategy, whereas $70.9 \%$ of them stated that their originations' strategic plan includes that.

Chi Square of independence was used to examine the association between department and the impact of social media on fundraising. As shown in Table 6, the results shows that there is no significant association between the department and the responses of the sample regarding the impact of the social medial on fundraising $(x 2=1.070$, $\mathrm{p}>0.05)$. Therefore, there are no significant differences in their responses. However, those working in programs department rank the highest (62.2\%), and those working in operations rank the lowest (51.7\%).

Table 6. Fundraising and the work department

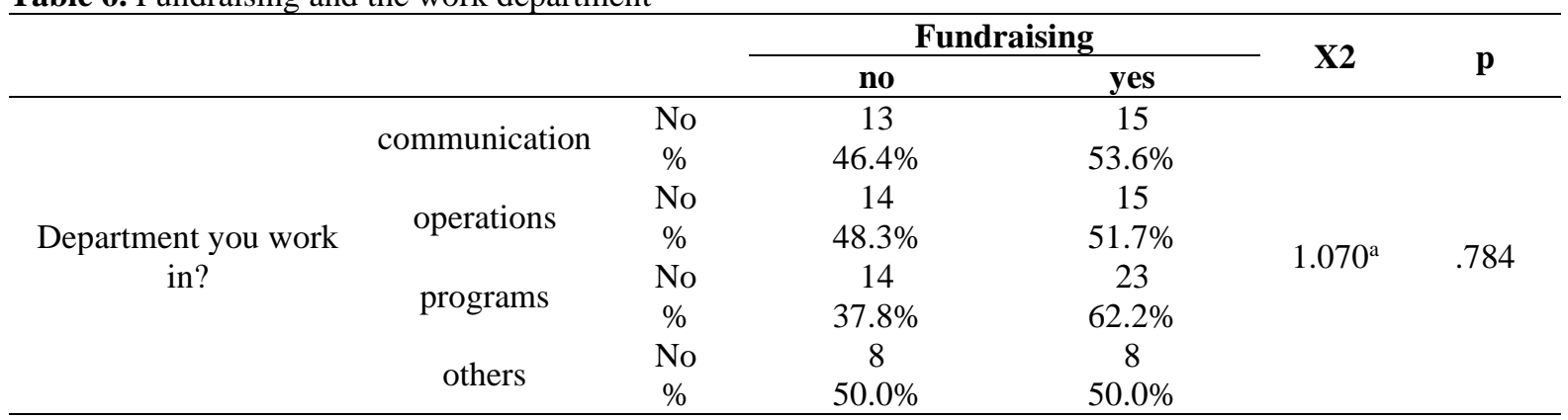

\section{Discussion and Conclusion}

The study indicates a high level of social media impact on brand awareness, community engagement, and organization performance at the UN agencies in Yemen. The study proved that the impact of social media is high rather than just a platform for fun. Social media is proved to create brand awareness among almost all people who use social media.

The majority of the respondents believe that social media platforms create brand awareness of the organization, which can tell about its activities, mission and vision. Mridha (2016), also, indicated that there are very important positive relationships between brand awareness of the nonprofit organizations' activities, mission, vision, etc and the usage of social media. This study focuses only on Facebook and Twitter as the two main social media platforms, whereas the study by Mridha (2016) studied all the social media platforms. 
It was not as expected that there will be a difference in the responses regarding the number of working years. The researchers assumes that people who have been working longer would have had stronger interaction and higher level of engagement through social media platforms. However, the majority of the respondents regardless of their number of working years believe that community engagement can be created through social media platforms. It is similar to the study by Vanga et al. (2019), which indicated that $80 \%$ of the respondents interact and follow brands of organizations through social media platforms. It is also in line with the second research by Cuillierier (2016), which indicated that $79 \%$ of the respondents believe in the community engagement through social media platforms and mainly through Facebook platform. This study indicating that the targeted audience can feel the tangible result of the social media impact on the different elements of performance.

The study proves that employees who work at the communication department strongly believe the performance of the organization can significantly get affected by social media platforms. This is not difficult to be proved as people in communication can see such impact by their own eyes. The level of the cost reduction communication can grant to the organization instead of using the old style of marketing is something that was proved in this study, which has similar results to the study by Dodokh (2017).

It was noticed that people in the programs come after the communication people. People working in programs have a better understanding of the relation of performance to the social media platforms than their operation colleagues because they are more in the field. The work they perform in the field and their understanding of social media platforms are attributed to the use of more innovative ideas to reach more people virtually.

Overall, the study proves that social media platforms have significant impact on the performance of organizations in many different aspects, which is exactly in line of agreement with the study by Dodokh (2017).

The study also indicates that there is no difference in the responses regarding the impact of social media on fundraising. However, the people working in the programs see that their work on social media platforms can significantly attract more fundraising in the future. This is in line with the study by Laird (2010). His study and this study see that better strategic planning in the area can affect positively the level of fundraising increment by better exploiting of social media platforms.

\section{Recommendations}

Based on the results of this study, the following recommendations should be considered by the UN agencies in Yemen:

- UN organizations and even all non-profit organizations in Yemen should keep and maintain the effective tools of social media platforms for many reasons.

- Organizations should raise full awareness of social media impact on the organizations among their inside people. Regardless of their ages, gender, number of working years, and most importantly the departments they work in, employees should have equal understanding of the impact of social media on the organizations. By raising this level of awareness by the organization itself among its own people, the major significant differences between the respondents will get less.

- The study indicates the great impact of social media platforms on the level of brand awareness and community engagement of the organization. UN agencies should work on maintaining this level and enhancing the idea widely. Therefore, other organizations in the country can work on achieving these two goals through the use of social media platforms.

- UN agencies in Yemen should work on their social media platforms to achieve tangible results for the organizations performance, as it is a critical objective for the use of social media platforms.

- UN agencies or even other nonprofit organizations in Yemen should have more strategic plans to raise fundraising through social media. Yemen is one of the most vulnerable countries, which needs consistent and huge fundraising to meet the need of the population. Social media platforms are effective tools to achieve this.

\section{Future Research}

This study focuses on the UN agencies in Yemen, and the targeted responses were taken mainly from the staff of these agencies. Future researches can study INGOs and even local organizations in the country. Moreover, even the targeted sample can be expanded to reach more people from the other side. Therefore, it could study the impact on the use of social media for beneficiaries. Since this study focuses only on the impact of social media on brand awareness, community engagement, performance and fundraising of the organizations, other studies can have different angles in their research. Therefore, the focus will be on how to apply these results through social media. 


\section{References}

Aaker, D. A. (1991). Managing brand equity: Capitalizing on the value of a brand name. Free Press; Maxwell Macmillan Canada; Maxwell Macmillan International.

Afonso, P., Nunes, M., Paisana, A., \& Braga, A. (2008). The influence of time-to-market and target costing in the new product development success. International Journal of Production Economics, 115(2), 559-568.

American Marketing Association. (2014). Definition of Brand (AMA Online Dictionary). Retrieved from https://www.ama.org/resources/Pages/Dictionary.aspx?dLetter=B\&dLetter=B

Barbole, A. N., Nalwade, Y. D., \& Parakh, S. D. (2013). Impact of cost control and cost reduction techniques on manufacturing sector. Indian Streams Research Journal, 3(5), 1-8.

Barnes, N. G. (2011). Social media usage now ubiquitous among US top charities, ahead of all other sectors. Retrieved from https://www.umassd.edu/media/umassdartmouth/cmr/studiesandresearch/charity201 $0 . p d f$

Barnes, N. G., \& Mattson, E. (2008). Still setting the pace in social media: The first longitudinal study of usage by the largest US charities. University of Massachusetts Dartmouth Center for Marketing Research.

Becker, K., Nobre, H., \& Kanabar, V. (2013). Monitoring and protecting company and brand reputation on social networks: When sites are not enough. Global Business and Economics Review, 15(2/3), 293. https://doi.org/10.1504/GBER.2013.053075

Berman, S. J., Abraham, S., Battino, B., Shipnuck, L., \& Neus, A. (2007). New business models for the new media world. Strategy \& Leadership, 35(4), 23-30. https://doi.org/10.1108/10878570710761354

Bortree, D. S., \& Seltzer, T. (2009). Dialogic strategies and outcomes: An analysis of environmental advocacy groups' Facebook profiles. Public Relations Review, 35(3), 317-319. https://doi.org/10.1016/j.pubrev.2009.05.002

Briones, R. L., Kuch, B., Liu, B. F., \& Jin, Y. (2011). Keeping up with the digital age: How the American Red Cross uses social media to build relationships. Public Relations Review, 37(1), 37-43. https://doi.org/10.1016/j.pubrev.2010.12.006

Byham, W. C., \& Moyer, R. P. (1996). Using competencies to build a successful organization. Development Dimensions International, Inc., 54(1), 61-80.

Calantonea, R. J., Cavusgil, S. T., \& Zhao, Y. (2002). Learning orientation, firm innovation capability, and firm performance. Industrial marketing management, 31(6), 515-524.

Cameron, K. S. (1984). Organizational studies program, national center for higher education management systems. Journal of Higher Education, 55(2), 220-300.

Chaston, I. \& Mangles, T. (1997). Core capabilities as predictors of growth potential in small manufacturing firms. Journal of Small Business Management, 3(5), 51-56.

Chen, I. J., \& Paulraj, A. (2004). Towards a theory of supply chain management: The constructs and measurements. Journal of operations management, 22(2), 119-150.

Cuillierier, A. (2016). Customer engagement through social media. Helsinki Metropolia University of Applied Sciences, 1-67. Retrieved from https://www.theseus.fi/bitstream/handle/10024/115812/Thesis Audrey Cuillierier - European and Business Administration.pdf?sequence=1

Dighe, A. (2002). Demographic and technological imperatives. In L. M. Salamon (Ed.), The state of nonprofit America (pp. 499-516). Brookings Institution Press.

Dodokh, A. M. I. (2017). The impact of social media usage on organizational performance: A field study on Dead Sea products companies in Jordan (Master's thesis, Middle East University). Amman, Jordan.

Dubois, D. D., \& Rothwell, W. J. (2004). Competency-based human resource management: Discover a new system for unleashing the productive power of exemplary performers. Nicholas Brealey.

Durkin, M., McGowan, P., \& McKeown, N. (2013). Exploring social media adoption in small to medium-sized enterprises in Ireland. Journal of Small Business and Enterprise Development, 20(4), 716-734. https://doi.org/10.1108/JSBED-08-2012-0094

Foster, A. (2014). Initiatives. Business Information Review, 31(2), 122-139.

Froelich, K. A. (1999). Diversification of revenue strategies: Evolving resource dependence in nonprofit organizations. Nonprofit and Voluntary Sector Quarterly, 28, 246-268.

Govette, J. (2014). Benefits of utilizing social media in the health care industry. ReferralMD Newsletter. Retrieved from: http://getreferralmd.com/2014/02/benefits-utilizingsocial-media-health-care-industry/

Greenberg, J., and MacAulay, M. (2009). NPO 2.0? Exploring the web presence of environmental nonprofit organizations in Canada. Global Media Journal-Canadian Edition, 2(1), 63-88.

Guo, C., \& Saxton, G. D. (2014). Tweeting social change: How social media are changing nonprofit advocacy. Nonprofit and Voluntary Sector Quarterly, 43(1), 57-79. https://doi.org/10.1177/0899764012471585

Gupta, A., Tyagi, M., \& Sharma, D. (2013). Use of social media marketing in healthcare. Journal of Health Management, 15(2), 293-302. 
Hollebeek, L. (2011). Exploring customer brand engagement: Definition and themes. Journal of Strategic Marketing, 19(7), 555-573. https://doi.org/10.1080/0965254X.2011.599493

How nonprofits can use social media to boost donations. (2020). [Blog post]. Retrieved from https://rb.gy/b5ip19

Ismail, A. R. (2017). The influence of perceived social media marketing activities on brand loyalty: The mediation effect of brand and value consciousness. Asia Pacific Journal of Marketing and Logistics, 29(1), 129144. https://doi.org/10.1108/APJML-10-2015-0154

Jeffery, M. (2010). Data-driven marketing: The 15 metrics everyone in marketing should know. John Wiley.

Kane, G. C., Alavi, M., \& Borgatti, S. P. (2014). What's different about social media networks? A framework and research agenda. MIS Quarterly, 38(1), 274-304. https://doi.org/10.25300/MISQ/2014/38.1.13

Kanter, B., \& Paine, K. (2012). Measuring the networked nonprofit using data to change the world. Hoboken: Wiley

Kaplan, A. M., \& Haenlein, M. (2010). Users of the world, unite! The challenges and opportunities of social media. Business Horizons, 53(1), 59-68. https://doi.org/10.1016/j.bushor.2009.09.003

Khan, G. F., Hoffman, M. C., \& Misztur, T. (2014). Best practices in social media at public, nonprofit, education, and health care organizations. Social Science Computer Review, 32(5), 571-574. https://doi.org/10.1177/0894439314525024

Kim, A. J., \& Ko, E. (2012). Do social media marketing activities enhance customer equity? An empirical study of luxury fashion brand. Journal of Business Research, 65(10), 1480-1486. https://doi.org/10.1016/j.jbusres.2011.10.014

Kumar, V. (2013). Profitable customer engagement: Concepts, metrics, and strategies. SAGE Publications India Pvt. Ltd.

Laird, M. (2010). Social media fundraising: Facebook friend or foe.

Li, S., Ragu-Nathan, B., Ragu-Nathan, T. S., \& Subba Rao, S. (2006). The impact of supply chain management practice on competitive advantage and organizational performance. Omega, 34(1), 107-124.

Logan, K., Bright, L. F., \& Gangadharbatla, H. (2012). Facebook versus television: Advertising value perceptions among females. Journal of Research in Interactive Marketing, 6(3), 164-179. https://doi.org/10.1108/17505931211274651

Lovejoy, K., \& Saxton, G. D. (2012). Information, community, and action: How nonprofit organizations use social media. Journal of Computer-Mediated Communication, 17(3), 337-353. https://doi.org/10.1111/j.10836101.2012.01576.x

Mridha, Md. (2016). Usage of Social Media by Non-Profit Organizations to Create Brand Awareness. Thesis, Jagannath University.

Matuszak, G. (2007). Enterprise 2.0: Fad or future? The business role for social software platforms. KPMG.

McCall, K. (2019). How to use social media for fundraising [Blog post]. Retrieved from https://www.rivaliq.com/blog/social-fundraising/

Mical, M. (2018). Impact of social media on nonprofits [Blog post]. Retrieved from https://micharity.com/impactof-social-media-on-nonprofits

Myers, S. \& Marquis, D. G. (2005). Successful industrial innovation: A study of factors underlying innovation in selected firms. National Science Foundation, 69-17.

Roscoe, J. T. (1975). Fundamental research statistics for the behavioral sciences (2d ed.). Holt, Rinehart and Winston.

Salem, S. F., \& Salem, S. O. (2019). Effects of social media marketing and selected marketing constructs on stages of brand loyalty. Global Business Review, https://doi.org/10.1177/0972150919830863

Sashi, C. M. (2012). Customer engagement, buyer-seller relationships, and social media. Management Decision, 50(2), 253-272. https://doi.org/10.1108/00251741211203551

Sekaran, U., \& Bougie, R. (2016). Research methods for business: A skill-building approach (7th ed.). Wiley.

Tapscott, D., \& Williams, A. D. (2006). Wikinomics: How mass collaboration changes everything. New York, NY: Portfolio.

Thornhill, S. (2006). Knowledge, innovation and firm performance in high- and low- technology regimes. Journal of Business Venturing, 21(1), 687-703.

Tiago, M. T., \& Veríssimo, J. M. C. (2014). Digital marketing and social media: Why bother? Business Horizons, 57(6), 703-708. https://doi.org/10.1016/j.bushor.2014.07.002

UN Yemen Report (2020). United Nations in Yemen report. Retrieved 10 December 2020, from https://yemen.un.org/en

Vacek, J. (2009). Innovation management. Department of Management, Innovations and Projects, UWB.

Van Haaften, R. (2017). Brand awareness. Retrieved from http://van-haaf-ten.nl/branding/corporate-branding/82brand-awareness 
Vanga, S. R., Yang, Y., \& Andersson, D. (2019). Perceptions and motivations of user engagement for social media marketing. $\quad$ Retrieved from http://www.divaportal.org/smash/record.jsf?pid=diva2\%3A1331530\&dswid=-2640

Vivek, S. D., Beatty, S. E., \& Morgan, R. M. (2012). Customer engagement: Exploring customer relationships beyond purchase. Journal of Marketing Theory and Practice, 20(2), 122-146. https://doi.org/10.2753/MTP1069-6679200201

Wasley, P. (2009). More charities are on social networks-but few have raised much. The Chronicle of Philanthropy, 21(14), 13-13.

Waters, R. D. (2007). Nonprofit organizations' use of the internet. Nonprofit Management \& Leadership, 18(1), 59-76. doi:10.1002/nml.171

Waters, R. D., \& Jamal, J. Y. (2011). Tweet, tweet, tweet: A content analysis of nonprofit organizations' Twitter updates. Public Relations Review, 37(3), 321-324. https://doi.org/10.1016/j.pubrev.2011.03.002

Waters, R. D., Burnett, E., Lamm, A., \& Lucas, J. (2009). Engaging stakeholders through social networking: How nonprofit organizations are using Facebook. Public Relations Review, 35(2), 102-106. https://doi.org/10.1016/j.pubrev.2009.01.006

Wilcox-Ugurlu, C. C. (2011). Social media, existence, identity dynamics and experiential consumption (Doctoral dissertation, University of Rhode Island). Retrieved from ProQuest Dissertations and Theses. (UMI No. 3454990).

Zhang, G., Johnston, C. \& Shao, C (2014). A Model for Optimally Promoting Application Diffusion on Facebook. International Journal of Marketing Studies, 6(4), 35-49. http://dx.doi.org/10.5539/ijms.v6n4p35

Lines, V. (2015). Time to market definition. Retrieved from www.ventureline.com

Saxton, G., (2013). The Social Network Effect: The Determinants of Giving Through Social Media. Nonprofit and Voluntary Sector Quarterly, 850- 868.

Indian University, (2011) https://generosityforlife.org/post-author/center-on-philanthropy-at-indiana-university/

\section{Copyrights}

Copyright for this article is retained by the author(s), with first publication rights granted to the journal. This is an open-access article distributed under the terms and conditions of the Creative Commons Attribution license (https://creativecommons.org/licenses/by-sa/4.0/). 